\title{
Commercializing Battery Storage for Integration of Renewable Energy in India: An Insight to Business Models
}

\author{
Dipen Paul $^{1 *}$, Dharmesh K. Mishra ${ }^{1}$, Arzaan Dordi ${ }^{2}$ \\ ${ }^{1}$ Symbiosis Institute of International Business, Symbiosis International (Deemed University), Pune 411057, India \\ ${ }^{2}$ MBA Energy Environment, Symbiosis Institute of International Business, Symbiosis International (Deemed University), Pune \\ 411057, India
}

Corresponding Author Email: dipen.paul@siib.ac.in

https://doi.org/10.18280/ijsdp.160419

Received: 29 January 2021

Accepted: 8 April 2021

\section{Keywords:}

battery storage, business models, energy storage systems, Li-Ion batteries, market drivers

\begin{abstract}
The research study focuses on exploring different business models that can be used for the deployment of battery storage in India. It further provides a perspective on the different business models adopted across the globe. It also focuses on the key market drivers that can be considered to build the country's storage ecosystem. The objective of the study was to bridge the gap between technology and commercialization. A comparative analysis of different business models adopted by other countries for battery storage and their relevance in the Indian Context was done. It also considered the business models that have been used in different sectors and looks feasible for the battery storage sector. The study recommends the model of "Trading stored electricity on Power Exchanges or Whole-Sale Market" and the model of "introducing battery storage as a package" as the most suitable models for implementation in the Indian context. Further the study identifies few critical factors for the success of commercializing battery storage in India which are choosing the right business model, knowing the needs of the customers and the Government's stand on policies.
\end{abstract}

\section{INTRODUCTION}

India ranks fourth globally in the renewable energy sector as per the Renewable Energy Attractiveness Index 2018 and fifth in terms of the total installed capacity. The renewable energy capacity is increasing at a CAGR of $17.28 \%$ between FY 14-18, with GW's total installed capacity (excluding Hydro) as of June 2019. Renewable energy will be the significant driver for meeting India's energy demand, with around $40 \%$ of its power needs to be fulfilled by renewables as mentioned in IBEF report on Indian Renewable Energy Industry Analysis [1].

It is evident from India's current scenario that renewable energy is becoming a cost-effective solution to promote socioeconomic development. The sector's competition is increasing, which is guaranteeing affordable energy and a reduction in price volatility. Although renewable energy is inconsistent, intermittent, and unpredictable, this causes uncertainty in electricity generation affecting all - the generator, the distributor, and the end consumer. These challenges need to be addressed to ensure the growth of the power sector. Also, India is focusing on Electric Vehicles (EVs) after renewable sources, to fulfil its pledge of the Paris Agreement 2015. The aim is to reduce its emission intensity of GDP by $33-35$ per cent by 2030 from 2005 levels as per the Centre for Science and Environment [2].

The storage of electricity will play a decisive role in enabling the next phase of the energy transition. There are various technologies for energy storage, but the capacity addition of battery storage system has been the highest in the past decade globally. So, battery storage is considered in this study. Battery Storage will help boost the solar and wind energy sector and help achieve a sustainable energy system. The adoption of electricity storage through battery technology will also help in decarbonizing the critical segments of energy use, predominantly transportation. The energy storage market is expected to grow to a market size of $\$ 160$ Billion in the short term to $\$ 300$ Billion by 2030 . Battery storage will have $50 \%$ of the energy storage market share globally, which is predicted to be replicated in India. Estimates show that the percentage of the battery storage system in India may even go up to $70-75 \%$ Enincon [3] India is expected to attract over \$3Billion in investments in the next three years and open up opportunities for manufacturing, assembly, R\&D, equipment supplies, and much more. Energetica [4] India is still in the formative stages of battery storage systems. As its potential unwinds in the country, it is bound to benefit the wide range of applications it caters too. With renewables and EVs the current focal points of the Indian Government, it is bound to satisfy the various stakeholders who will be engaged with this segment. The numerous benefits that battery storage brings will ensure that it plays a pivotal role in the country's energy transition. The battery storage system has services like frequency regulation, grid frequency management, improves the quality of power, reduces peak shaving, load management, grid stabilization, ensures backup power in case of grid failure, and constant power output over time. Frankel and Wagner [5] and Ralon et al. [6] mentioned that the ranges of services that electricity storage can offer are Bulk Energy Services, Ancillary services, transmission and distribution infrastructure services, customer energy management services, off-grid transport sector, etc.

Akhil et al. [7] described that the battery storage comes 
under the electrochemical form of energy storage and has various chemistries that are used across applications. Battery chemistry will play a crucial role in deciding the economics of the battery energy storage system. It is important to note that with change in inherent characteristics of battery chemistry the costs of the battery energy storage system is bound to change. Hence, it becomes important to select the right battery chemistry and promote indigenous manufacturing for the same. The types of battery and their details are mentioned below:

-Lithium-Ion Batteries: These batteries have a high energy density, making them useful for portable electronics and EVs. High-cycle efficiency and fast response times are other advantages of Li-Ion batteries.
-Nickel-based Batteries: High energy density and reliability are advantages of this battery.

-Sodium-based Batteries: They require high operating temperatures and are suitable for long-discharge applications.

- Lead Acid Batteries: One of the oldest forms of battery storage, lead-acid battery development, began in the mid1800 s. Although, it has low energy density and cycle lift.

-Flow Batteries: Flow batteries have a long cycle and operational life. They have more than one chemical component in a liquid solution. They are typically stored in tanks.

-The performance characteristics of each battery are given in the Table 1:

Table 1. Performance characteristics of the battery $[8,9]$

\begin{tabular}{|c|c|c|c|c|}
\hline $\begin{array}{c}\text { Performance } \\
\text { Characteristics }\end{array}$ & Li-Ion Batteries & Nickel Cadmium & $\begin{array}{c}\text { Sodium Sulphur (NaS) } \\
\text { Batteries }\end{array}$ & Lead Acid Batteries \\
\hline Energy Density - Wh/ kg & $90-150$ & $45-80$ & 128 & $30-50$ \\
\hline Safety Requirements & $\begin{array}{l}\text { Protection Circuit } \\
\text { required }\end{array}$ & $\begin{array}{l}\text { Common fuse } \\
\text { protection required as it } \\
\text { is Thermally Stable }\end{array}$ & $\begin{array}{c}\text { The system must be protected } \\
\text { with a water and oxidizing } \\
\text { atmosphere }\end{array}$ & $\begin{array}{l}\text { Common fuse } \\
\text { protection required as } \\
\text { it is Thermally Stable }\end{array}$ \\
\hline Maintenance & Not Required & $\begin{array}{c}30-60 \\
\text { days (discharge) }\end{array}$ & Very low & $\begin{array}{c}3-6 \\
\text { months (topping up) }\end{array}$ \\
\hline Life Cycle - in cycles & $500-2000$ & 1000 & 4500 & $200-300$ \\
\hline
\end{tabular}

Table 2. Advantages and disadvantages of battery [10]

\begin{tabular}{|c|c|c|}
\hline Battery Technology & Advantages & Disadvantages \\
\hline Li-Ion Batteries & $\begin{array}{l}\text { Quick response to charge and discharge operations, } \\
\text { Very high efficiency (closer to } 100 \% \text { ), and density. }\end{array}$ & $\begin{array}{l}\text { Degradation of the battery starts at high temperature; } \\
\text { Cost of battery is high }\end{array}$ \\
\hline $\begin{array}{l}\text { Nickel Cadmium (Ni-Cd) } \\
\text { Batteries }\end{array}$ & $\begin{array}{l}\text { High mechanical resistance, Suitable for power tools, } \\
\text { emergency lightings, and portable devices }\end{array}$ & Cd is highly toxic for the environment \\
\hline $\begin{array}{l}\text { Sodium Sulphur (NaS) } \\
\text { Batteries }\end{array}$ & $\begin{array}{l}\text { Economical for power quality and peak shaving } \\
\text { purposes. Economical and relatively efficient }\end{array}$ & $\begin{array}{l}\text { The heat source is required as the battery is unable } \\
\text { to work at normal conditions due to the presence of } \\
\text { sodium }\end{array}$ \\
\hline Lead Acid Batteries & $\begin{array}{l}\text { Reliable, easy to replace, low cost and mature } \\
\text { technology }\end{array}$ & $\begin{array}{l}\text { Relatively high maintenance cost, low energy } \\
\text { density. Lead has an environmental hazard }\end{array}$ \\
\hline
\end{tabular}

The advantages and disadvantages of different technologies mentioned above are as Table 2 .

\section{Li-ion battery price outlook $\$ / \mathrm{kWh}$}

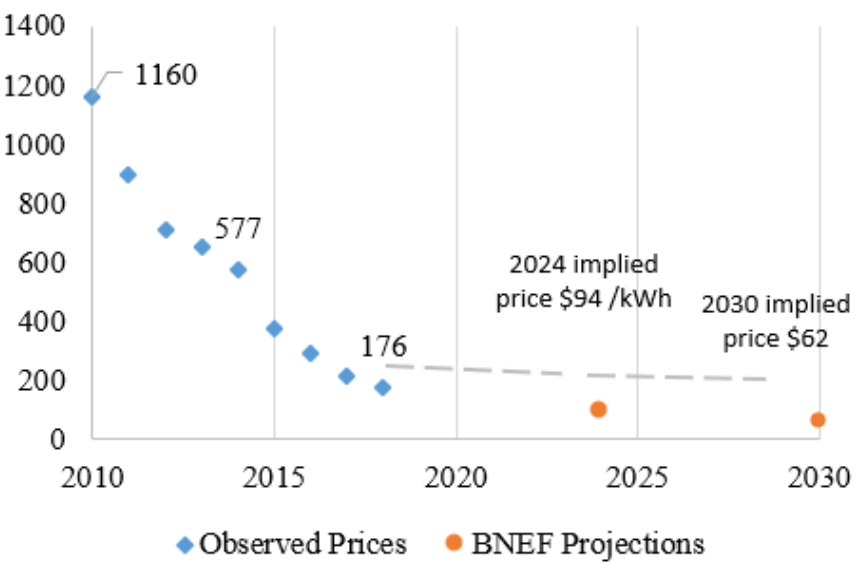

Figure 1. Li-ion battery price outlook Source: Bloomberg new energy finance, 2019

Out of the types mentioned above, the world is focussed on Li-Ion batteries because of the widely used applications, right from grid supporting and balancing which may have to discharge time of few minutes to hours, to Fast Response
System have to discharge timings of seconds. Further, the higher efficiency and mid-range power and energy capacity costs make it widely available. Other technologies that are looked into are nickel-based batteries and flow-based batteries

In the current scenario, with the growing market for renewables and electric vehicles countries in Asia, the United States and Europe are scaling up production to serve the enormous market potential. Around 2010, the battery pack cost around $\$ 1000$ per kilowatt-hour, which was unviable for the commercial application. However, now the electricity storage prices are falling with a battery pack costing $\$ 230$ per kilowatt-hour in 2016. Frankel and Wagner [11] explained the trend of battery pack cost globally is given in Figure 1.

Figure 1 clearly shows that even by considering the optimistic and pessimistic scenarios, the battery pack prices will further fall to $\$ 175-\$ 210 / \mathrm{kWh}$ in 2020 and $\$ 100$ $\$ 130 / \mathrm{kWh}$ dollars in 2030 . The numbers indicate that the storage is now an economical option for commercial use. With these prices, battery storage will be the next disruptive technology and will play a crucial role in providing renewable energy integration and electrical mobility to the world. India has a significant economic opportunity for battery manufacturing. Although India's global position is weak, the country's market potential is bringing in keen interest by companies in India and across the globe. Make in India campaign if implemented in the right spirit for battery manufacturing can see India undergo a radical industrial and 
economic transformation and compete in the global market. The Government of India is conscious of this fact and has constituted an Inter-Ministerial Steering Committee chaired by CEO, Niti Aayog. The objective of this committee is to implement an overarching programme framework and policylevel initiatives for overall demand creation to ensure Domestic Giga Scale Battery Manufacturing in India.

Along-side manufacturing, it is crucial to understand the current viability of battery storage in sectors of renewables and EVs. We need to identify the key market drivers who will facilitate in spreading of this technology. Stable and transparent policies, coordinating with stakeholders, and understanding the investors' challenges will be critical to the success of battery storage in India.

This paper provides a perspective on the different business models adopted across the globe. It also focuses on the key market drivers that can be considered to build the country's storage ecosystem. India's Power Sector construct is compared to none; hence, it becomes essential to understand each of the Business Models' relevance in the Indian Power sector context and rank the business models based on the key drivers. Ranking helps to funnel out the business models which can be taken up with least changes to the existing construct of the power sector. Although, it does not indicate that the lower ranked business models cannot be considered in the future. Completing this exercise helps shortlist the business models and provide recommendations to help the stakeholders plan the way forward for grid-scale deployment of the country's battery storage system.

The paper further flows into the objective in Section 2, 'method' adopted to review six different business models adopted by other countries and the market drivers in Section 3, 'analysis and interpretation' of the models in the Indian Context is discussed in Section 4, and finally 'conclusion' and recommendations in Section 6.

\section{OBJECTIVE}

The study focuses on exploring different business models that can be used for the deployment of battery storage. The objective is to bridge the gap between technology and commercialization. The battery storage industry has seen many revolutionary developments on the technology front but commercializing the same is a real challenge [12].

In a country like India, where battery storage technology will play a vital role in the success of renewable energy installation, it is essential to figure out a feasible way to approach the untapped market potential so that everyone can be benefitted.

This study will help as a reference guide to facilitate quick decision-making for corporate houses willing to enter India's battery storage business. It will also give a holistic view of the current scenario, business models, government policies, opportunities, and challenges associated with battery storage.

\section{METHODOLOGY}

This study has done a comparative analysis of different business models adopted by other countries (or planning to do so) for battery storage and their relevance in the Indian Context. It also considers the business models that have been used in different sectors and look feasible for the battery storage sector. Market drivers for battery storage business in the country are also identified which will help rate the business models and identify the gap between the already existing parameters and the challenges that the country will face in commercializing battery storage.

\section{BUSINESS MODELS FOR BATTERY STORAGE}

To succeed in the new market of battery storage, it is of utmost importance to experiment, prepare, and develop different business models. Identifying the right business model and critical success indicators will help companies be future market leaders. This segment will focus on different countries' different business models and know which the most optimum model in the Indian Context will be.

The business models can vary depending upon the application of battery usage. In some countries, the business models are divided based on the capacity of installation and type of investment done. They vary depending on the energy system's value chain right from generators, System and Network operators to end-users. As battery storage caters to different needs, as shown in Figure 1, a unique business and revenue model is required. The models can surround the fundamental advantage that battery storage offers to balance demand and supply, peak shaving, acting as a backup power source, and renewable power integration [13]. Some of the models are discussed below.

\subsection{Business model 1: Trading stored electricity on power exchanges or whole-sale market}

The intermittent power supply is standard in renewable energy as the generation depends on the solar irradiation and the wind potential. For example, the Total output of a wind or solar plant can vary as much as $20 \mathrm{GW}$ for one region of Germany alone. Pillot [14] explains that the battery storage can ensure that sufficient back up is available when renewables fail to deliver. To ensure this, energy needs to be stored when the renewables are providing adequate electricity, and battery backup can come in when the shortfall occurs. This model can work best if it is driven by market demand and supply. Thus, power exchanges can help set up a marketclearing volume and market-clearing price for electricity supply. Here, the "demand response aggregator/ generation company" needs to collate the bids such that they can have a good price at the exchange. This model needs to be carefully regulated with strict guidelines and should have a regulatory body and a grievance platform to ensure smooth operation.

In the Wholesale market, one can win auctions for their predescribed capacity of electricity. In India generators and buyers come on the exchange platform to buy and sell power through the Indian Energy Exchange. The participants in this process are the distribution companies, producers and consumers. The participants can purchase electricity through intra-day contracts (same day), day-ahead contingency(next day), and daily and weekly contracts to manage their electricity portfolio for different durations [15]. This can help the ancillary service segment that battery storage can offer. Example: Germany has opened up a Primary Control Reserve (PCR) market, which is proof of this model's concept [16]. In this market, revenue is generated by a weekly auction. The auctioned amount is then paid to the service provider depending upon the capacity used to balance the grid. As 
battery storage can instantly respond to the system imbalances, they directly compete with the gas Peaker plants, an established technology. Secondary Control Reserve Markets are also an option that reduces grid imbalance on the distribution side. Companies like Hitachi, Panasonic, Restore, KiWi Power, and many others are developing DR aggregator platforms for smooth trading. The US has also started opening its wholesale market for battery storage, focusing on rewarding the players with speed and accuracy for grid stabilization.

\subsection{Business model 2: Asset ownership by TRANCOs and/or DISCOMs}

In the Asset Ownership Model, the Transmission Service Companies (TRANSCOs) or Distribution Companies (DISCOMs) will own and operate the battery storage system. The use of the battery storage system will be to avoid congestion and for peak shaving. The revenue will come through a fixed pre-decided rate by the regulator. The same price can be recovered from the customer under the head of transmission and distribution line maintenance. This may sometimes question the viability of specific projects. Example: This model is currently active in the United States and the United Kingdom. The operators own small systems, although third-party sources the operations. In countries like Italy and Belgium, all systems are owned and operated by battery providers. This model is also tested on a trial basis by Oncor in Texas [17].

\subsection{Business model 3: Third-party ownership model}

Adopted by the US and Germany, this model brings in a third-party responsible for the owning and operating of the battery storage system. Here, the third party is free to provide its services to any DISCOM or TRANSCO. The third-party developer can decide whether it will sell the services on a fixed-term basis with the system operators or trade it on the power exchange. Thus, it creates multiple revenue streams for the battery system operator making the model viable. This model will also cater to services like renewable energy integration, black start, and frequency response. It can cater to both small scale and utility-scale projects. Example: This model is currently active and is practised in the United States and Germany [18]

\subsection{Business model 4: Operational expenditure (OPEX) model}

Like the solar rooftop models, the battery storage can also adopt the OPEX model. The battery storage company invests the battery storage capital cost, and the consumer of the services will have to pay a fixed pre-defined price which will be less than the price availed from the DISCOMs. This model can increase the footprint of battery storage users as it doesn't involve initial capital cost from the customer end. Example: In India, according to the latest proposed amendment of the Electricity Act, 2018, Renewable Energy Service Companies (RESCOs) are introduced which function on the OPEX model. It is seen that with the introduction of the OPEX model, the solar rooftop sector for commercial and industrial consumers has increased by $35 \%$. It provides a win-win situation to both the developer and the consumer $[19,20]$.

\subsection{Business model 5: Community battery storage model}

A colony of houses can have a standard battery bank set-up for them which can be used to ensure peak shaving and avoid blackouts. The operation and maintenance cost of the battery bank will be of the company that installs the set-up and the asset ownership. Here, the surplus renewable energy is stored in the battery bank, and the consumer receives credit for the same [21]. At the time of peak demand or blackout, the consumer can use up the battery backup. Initially, battery credit is utilized at no cost. Once it exceeds the credit that was available, the pre-decided rates are applied in your electricity bill. This ensures you get the benefit of units that you had initially stored in the battery. The challenge to this model is to have a robust smart grid and microgrid infrastructure. Example: This model has been tested as a pilot project for battery storage at the White Gum Valley in Australia. Community Model has been adopted in India in the boiler manufacturing and in combined heat and power solutions segment by providing centralizing steam generation and distribution in large Industrial Development Corporations to facilitate ease of manufacturing in industries without worrying about compliance which is necessary for setting up individual boilers.

\subsection{Business model 6: Solar plus battery storage - a long- term solution}

This business model encourages solar developers to install battery storage with the installation of solar PV projects [22]. Although there are technical bottlenecks that are currently hindering the progress of this model, it can be a great success in the next five years. Partnerships between battery storage manufacturers and solar developers are seen in many countries like the US, Germany, the UK, etc. This model can be quickly brought into implementation by minimum regulatory changes and a slight push from the respective countries' governments. Example: Western Australia tested this model in 2016 for the residential sector. In 2017, the Government announced the funding of $\$ 17$ million to support four similar projects. This model's success depends upon the reducing price of battery storage and the adoption of a packaged solution by the residential sector. India has initiated this model for pilot testing with Kerala's ANERT installing a hybrid project with utility-scale battery storage Kerala Power Department [23]. In India, this business model can be clubbed with the OPEX business model to facilitate faster adoption of battery storage in the country Sapna Goel [24]

\section{MARKET DRIVERS FOR INDIAN BATTERY STORAGE MARKET}

In the Indian context, it is essential to identify the key market drivers that would help establish the battery storage ecosystem for the businesses to flourish. According to CARE Ratings [25], the below segment highlights these critical parameters in detail:

\subsection{Regulatory framework}

The regulatory framework is a backbone for the success of any new technology in the country. The Government plays a pivotal role in attracting investors into an industry. The electricity sector in India has seen significant growth in energy 
demand and generation capacity. This has also pushed the development of transmission and distribution networks. India's electricity sector is a concurrent subject with the centre and state government having equal responsibility for growth, operation, and control. The centre frames overall regulations and subsequent state regulations and policies are made. For roll-out of battery storage in India, it will be necessary to come up with a central Act or have amendments in the existing Electricity Act which will act as an umbrella for the central policies to follow. The Government of India's NITI Aayog, has come up with "India's Energy Storage Mission", to provide a three-stage solution approach of developing an environment for battery manufacturing, scaling up of supply chain and developing related strategies and increasing battery cell manufacturing SMARTNET [26].

\subsection{Infrastructure development}

India achieved 100\% electrification in January 2019 by providing electricity to 2.44 crore households under the Pradhan Mantri Sahaj Bijli Har Ghar Yojna (Saubhagya scheme) Press Trust of India [27]. Approximately 350 GW Saubhagya MoP [28] of power plants' installed capacity will help provide $24 \times 7$ power to all. This shows the importance of infrastructure for the development of any sector. Battery storage can realize its true potential only when the infrastructure will be robust and interconnected. The strong network of microgrids and smart grids' adoption shall be critical to a bright future for battery storage. In India, microgrids' adoption is at its inception stage where only 63 solar microgrids of $1,899 \mathrm{kWp}$ have been installed. According to Prateek [29], this needs to increase four-fold to support different business models and ensure projects' financial viability.

\subsection{Political stability}

The Government in the realm shows the vision and direction for an industry to move forward. In a country like India, where the Power sector is highly regulated, it is essential to have uniformity in vision in the years to come. It is no guess that a stable government with a long-term vision will be beneficial in this incubation stage of battery storage.

\subsection{Economic feasibility}

To ensure the success of battery storage, it is essential to have the projects' economic feasibility. Revenue recovery should be higher and must be supported by infrastructure development and regulatory framework. Multiple revenue streams encourage investors to invest in battery storage technology. California has allowed various revenue streams for battery storage system in a generation, transmission, and distribution. It is also the first state to do so. This step helps move towards economic feasibility [16]. The drop of battery storage prices over the years is steadily on a decline, as shown in Figure 1. This will make the financial models read higher ROI on projects attracting more investment. In the long run, economies of scale will ensure a reduction in manufacturing costs and an increase in profit margins.

\subsection{Financial incentives}

The Government of India can roll out financial incentives for the business models they deem fit and promote. Once the financial incentives are announced, businesses try to encash on the opportunity. For battery storage financial incentives like tax rebates, low-interest financing, or reduction of battery system costs can be considered. India can begin with a FeedIn-Tariff regime to woo investors for the development of solar projects.

Further, for battery manufacturing Niti Aayog in June'20, has proposed a 2-tier incentive structure. In this structure, a minimum support will be provided to the entire industry for advanced chemistry-cell manufacturing. Additional incentives may be provided to advanced chemistry cell manufacturers at giga scale levels with cumulative capacity of $50 \mathrm{GWh}$.

To boost indigenous battery manufacturing, investment linked tax incentive may be taken up followed by a structured approach to limit imports by applying custom duties as in the case of solar modules.

\section{RESULTS AND DISCUSSIONS}

\subsection{Relevance of business models in the current Indian scenario}

This section focusses on whether or not the business models proposed earlier can be considered in the Indian Context. It will also focus on some of the challenges that the country has in adopting battery storage and which models can be brought into effect at the earliest. Some examples of existing projects will be given to have a brief insight into the stage in which these models are global [30].

Table 3 shows which parameters are available in the current Indian Context and the areas we need to focus on. Accordingly, the business model 1 of 'Trading stored electricity on Power Exchanges' has the right regulations in place, the required infrastructure, and is tried and tested for economic feasibility in the short term. The Indian Energy Exchange and the Power Exchange of India Ltd. are a power exchange platform that trades electricity through various mechanisms like Day Ahead Markets and Term Ahead Markets. This business model can be replicated for battery storage by aggregating the Demand Response (DR) and Supply Response and coming to a Market Clearing Volume (MCV) and Market Clearing Price (MCP). This can take place once the adequate infrastructure of the smart and microgrid is established in the country. No policies or regulations are currently allowing TRANSCOs and DISCOMs to share assets (Model 2) and use them for business purposes.

The third-party ownership model (Model 3) is similar to the CAPEX model, where a third party will invest initially for a pre-defined customer. This model is analogous to the ESCOs (Energy Service Companies) where they will focus on the ancillary services like black start and frequency response. The regulatory framework can be considered present as minimal changes need to be made to existing policies. Also, the economic feasibility of this model in the long-run is checked. US and Germany are experimenting with this model, although it requires robust smart-grid infrastructure for this model's financial feasibility in India. 
Table 3. Relevance of business models in the current Indian scenario

( $\checkmark$ : Already existing in India, X: Challenges or Bottlenecks)

\begin{tabular}{|c|c|c|c|}
\hline \multirow[b]{2}{*}{ Business Models } & \multicolumn{3}{|c|}{$\begin{array}{l}\text { Key Parameters already existing for different Business Models in the Indian } \\
\text { Context }\end{array}$} \\
\hline & $\begin{array}{l}\text { Regulatory } \\
\text { Framework }\end{array}$ & $\begin{array}{l}\text { Infrastructure } \\
\text { Development }\end{array}$ & $\begin{array}{l}\text { Economic Feasibility in the } \\
\text { short term }\end{array}$ \\
\hline $\begin{array}{c}\text { Power Exchange or Whole-sale Business } \\
\text { Model }\end{array}$ & & $\checkmark$ & $\checkmark$ \\
\hline $\begin{array}{l}\text { Asset Ownership by TRANSCOs } \\
\text { and/or DISCOMs }\end{array}$ & $\mathrm{X}$ & $\mathrm{X}$ & $\checkmark$ \\
\hline Third-Party Ownership Model & $\checkmark$ & $\mathrm{X}$ & $\checkmark$ \\
\hline Operational Expenditure Model & $\checkmark$ & $\mathrm{X}$ & $\checkmark$ \\
\hline Community Battery Storage Model & $\mathrm{X}$ & $\mathrm{X}$ & $\mathbf{X}$ \\
\hline Solar + Battery Storage - A long-term solution & $\mathbf{X}$ & $\mathbf{X}$ & $\mathbf{X}$ \\
\hline
\end{tabular}

Solar rooftop projects in India are now being installed under the OPEX business model (Model 4). The 2017 amendment to the Electricity Act, 2003 opens up the use of this model even further for the solar sector. This model can be looked into for battery storage, too, as the existing players know the difficulty and challenges that this model faces. Although the lack of existing solar rooftops with this model as compared to the conventional model can pose a hindrance. Hence, it can be looked into in the second phase of rolling out battery storage.

Steam House is a Surat-based company that provides solutions for Community Boiler and plans to set up high capacity boilers that can cater to a complete industrial park. Similarly, a community-based model (Model 5) can be considered for battery storage as well. This will require the building of micro-grid infrastructure, which will make it is easy for this model to be deployed. Australia started a pilot project in 2015 to see the economic feasibility of the project. This model has an additional challenge of aggregating demand for individual customers and providing them customized solutions as per their requirements.

Another business model that can be considered to be most likely of adoption is the Battery Storage and Solar PV package model. This model has been tested in Australia, and the Government has funded it with $\$ 17$ million in 2017. Initial reports suggest that the entire system's payback period will begin by 9-12 years, which is higher than the current 5-7-year payback. Considering the current scenario, customers are unwilling to invest in a product that has a 5years payback; hence, this model will require the government's subsidy to come into effect.

In India, Tata Power has set up a $10 \mathrm{MW/} 10 \mathrm{MWh}$ Grid Energy Storage System. Andhra Pradesh Transmission Company (APTRANSCO) \& Madhya Pradesh Power Management Corporation Limited (MPPMCL) have come outwith Expression of Interests (EOI)of $400 \mathrm{MW} \& 500 \mathrm{MW}$ ESS respectively. Also, CEA has come up with a Draft Optimal Generation Report that identifies the need for and quantifies Battery Energy Storage System'(BESS) optimal size. It has identified a $\sim 34 \mathrm{GW} / 136 \mathrm{GWh}$ potential for BESS in India. The major challenges in deploying battery storage include the battery's location (generation end, transmission end, or distribution) and setting up a mechanism for cost recovery (sharing of tariff) [31].

\section{CONCLUSION}

India has grown its renewable energy capacity in the energy mix, making a compelling case for battery storage adoption at the earliest. The market dynamics are changing with the battery prices falling, and it is imperative to take steps to commercialize this technology so that we are not found lagging in the next decade. Business models and critical market drivers are identified which need to be taken up for discussion soon to create a mandate that will benefit this industry's growth. There are challenges of infrastructure and economic feasibility, and that is where the Government's role will come in. The study recommends six business models that can be considered for adoption with model of trading at power exchanges and model of introducing battery storage as a package can be regarded as the most suitable one. We have the basic requirements of infrastructure and regulatory framework to try this model with minimum risk.

The first and foremost objective will be to increase the infrastructure of microgrids in the country. Once this is created, model 1 can be rolled out for testing. The Government might also think of going ahead with Feed-in-Tariffs similar to solar in initial years to boost private investment. The Government can also look into a different vertical to use battery storage during the operation and maintenance of power plants, as discussed in Model 6. This will enable less burden on the grid and also help in reducing the risks of blackouts.

\section{REFERENCES}

[1] IBEF, Indian Brand Equity Foundation. (2019). Indian Renewable Energy Industry Analysis. https://www.ibef.org/download/Renewable-EnergyAugust-2019.pdf.

[2] CSE, Centre for Science and Environment. (2019). Coping with Climate Change. http://www.indiaenvironmentportal.org.in/files/file/copi ng-climate-change-NAPCC.pdf.

[3] Enincon. (2018). Battery Energy Storage Systems for Off-Grid \& Grid Scale Installations in India. Available: https:/enincon.com/wp-ontent/uploads/2018/01/BESSMarket-in-India-2018_Flyer.pdf.

[4] Energetica. (2019). India's Energy storage Market. https:/www.energetica-india.net/articles/indias-energystorage-market.

[5] Frankel, D., Wagner, A. (2017). Battery storage: The next disruptive technology in the power sector. McKinsey. $\quad \mathrm{https} / /$ www.mckinsey.com/businessfunctions/sustainability-and-resource-productivity/ourinsights/battery-storage-the-next-disruptive-technologyin-the-power-sector.

[6] Ralon, P., Taylor, M., Ilas, A., Diaz-Bone, H., Kairies, K. 
(2017). Electricity storage and renewables: Costs and markets to 2030. International Renewable Energy Agency: Abu Dhabi, UAE.

[7] Akhil, A.A., Huff, G., Currier, A.B., Kaun, B.C., Rastler, D.M., Chen, S., Gauntlett, W.D. (2013). DOE/EPRI 2013 electricity storage handbook in collaboration with NRECA (p. 340). Albuquerque, NM: Sandia National Laboratories.

[8] Akhil, A.A., Huff, G., Currier, A.B., Kaun, B.C., Rastler, D.M., Chen, S.B., Gauntlett, W.D. (2015). DOE/EPRI electricity storage handbook in collaboration with NRECA. Sandia National Laboratories.

[9] Hesse, H.C., Schimpe, M., Kucevic, D., Jossen, A (2017). Lithium-ion battery storage for the gridAreview of stationary battery storage system design tailored for applications in modern power grids. Energies, 10(12). https://doi:10.3390/en10122107

[10] Akinyele, D., Belikov, J., Levron, Y. (2017). Battery storage technologies for electrical applications: Impact in stand-alone photovoltaic systems. Energies, 10(11): 1760. https://doi.org/10.3390/en10111760

[11] Frankel, D., Wagner, A. (2017). Battery storage: The next disruptive technology in the power sector. McKinsey. https://www.mckinsey.com/businessfunctions/sustainability-and-resource-productivity/ourinsights/battery-storage-the-next-disruptive-technologyin- the-power-sector.

[12] Li, X., Chalvatzis, K.J., Stephanides, P., Papapostolou, C., Kondyli, E., Kaldellis, K., Zafirakis, D. (2019). Bringing innovation to market: business models for battery storage. Energy Procedia, 159: 327-332. https://doi.org/10.1016/j.egypro.2019.01.007

[13] Bradbury, S., Hayling, J., Papadopoulis, P., Heyward, N. (2013). Smarter Network Storage. UK Power Networks.

[14] Pillot, C. (2017). Avicenne Energy. Information for Growth.

[15] Alam, F., Alam, Q., Reza, S., Khurshid-ul-Alam, S.M., Saleque, K., Chowdhury, H. (2017). Regional power trading and energy exchange platforms. Energy Procedia, 110: $592-596$ https://doi.org/10.1016/j.egypro.2017.03.190

[16] Sutherland, B.R. (2019). Charging up stationary energy storage. Joule, 3(1): 1-3.

[17] Gissey, G.C., Dodds, P.E., Radcliffe, J. (2018). Market and regulatory barriers to electrical energy storage innovation. Renewable and Sustainable Energy Reviews, 82: 781-790. https://doi.org/10.1016/j.rser.2017.09.079

[18] ISGF, India Smart Grid Forum. (2019). Smart Grid handbook of regulators and policy makers. http://indiasmartgrid.org/document/Draft_Smart\%20Gri $\mathrm{d} \% 20$ Handbook $\% 20$ for $\% 20$ Regulators $\% 20$ and $\% 20$ Poli cy $\% 20$ Makers compressed $\% 20(1)$.pdf.

[19] Trivedi, S., Ray, I., Vulturius, G. (2018). Scaling up
Rooftop Solar Power in India: The Potential of Solar Municipal Bonds.

[20] Rathore, P.K.S., Chauhan, D.S., Singh, R.P. (2019). Decentralized solar rooftop photovoltaic in India: On the path of sustainable energy security. Renewable Energy, 131: 297-307. https://doi.org/10.1016/j.renene.2018.07.049

[21] Van Der Stelt, S., AlSkaif, T., van Sark, W. (2018). Techno-economic analysis of household and community energy storage for residential prosumers with smart appliances. Applied Energy, 209: 266-276. https://doi.org/10.1016/j.apenergy.2017.10.096

[22] Marwali, M.K.C., Haili, M.A., Shahidehpour, S.M., Abdul-Rahman, K.H. (1998). Short term generation scheduling in photovoltaic-utility grid with battery storage. IEEE Transactions on Power Systems, 13(3): 1057- 1062. https://doi.org/10.1109/59.709099

[23] GoK, Goverenment of Kerala, Power department, File No. PWR- PS2/150/2018-POWER. (2019). https://www.anert.gov.in/sites/default/files/inlinefiles/AS\%202018-19.pdf.

[24] Gopal, S. (2019). Best of 2018: Wind-solar hybrid policy to boost renewables. Available: https:/indiaclimatedialogue.net/2018/1 2/28/wind-solarhybrid-policy-to-boost-renewables-push-2/.

[25] CARE Ratings. (2019). Firming up solar energy with energy storage systems. http://www.careratings.com/upload/NewsFiles/Studies/ Solar\%20Roop $\% 20$ top $\% 20$ and $\% 20$ Energy $\% 20$ Storage. pdf.

[26] Smartnet. (2019). India's Energy Storage Mission: A Make-in- India Opportunity for Globally Competitive Battery Manufacturing. https://smartnet.niua.org/content/05546d8c-1b34-4cc69f3b-371d7b7225a7.

[27] PTI, Press Trust of India. (2019). India likely to achieve universal household electrification by Jan-end. http://ptinews.com/news/10325011_India-likely-toachieve-universal-household-electrification-by-Jan-end.

[28] Saubhagya. (2019). Ministry of Power. https://powermin.nic.in/.

[29] Prateek, S. (2019). Micro and Mini Grids Could be the Answer to Grid Stability and Reliable Power in India. https://mercomindia.com/micro-mini-grid-indiademand- grid-stability/.

[30] Frost \& Sullivan. (2017). Emerging Business Models in the Global ESS Market, 2017. https://store.frost.com/emerging-business-models-inthe-global-ess-market-2017.html.

[31] MOP, Ministry of Power, GOI, CEA. (2019). Draft report of Optimal Generation Capacity Mix for 2029-30. http://cea.nic.in/reports/others/planning/irp/Optimal_ge neration_mix_report.pdf. 